\title{
Art of Maternal Womb Painting: term, concept, and technique
}

\author{
Arte da pintura do ventre materno: termo, conceito e técnica \\ Arte de la Pintura del Vientre Materno: termo, concepto y técnica
}

\section{Júnia Aparecida Laia da Mata' \\ ORCID: 0000-0001-9062-8536}

Antonieta Keiko Kakuda Shimo' ORCID: 0000-0001-7377-4590

'Universidade Estadual de Campinas. Campinas, São Paulo, Brazil.

How to cite this article: Mata JAL, Shimo AKK. Art of Maternal Womb Painting: term, concept, and technique. Rev Bras Enferm. 2019;72(Suppl 3):32-40. doi: http://dx.doi.org/10.1590/0034-7167-2017-0726

\section{Corresponding Author:}

Júnia Aparecida Laia da Mata E-mail: jumata.2905@gmail.com

Submission: 10-22-2017 Approval: 06-08-2018

\section{ABSTRACT}

Objective: to present the term, concept and technique of art of maternal womb painting Method: a theoretical, exploratory and qualitative study. Results: from the results, the concept was elaborated and based on linguistic, philosophical and specialized perspective. The concept and technique of Art of Maternal Womb Painting were guided by humanism and holism. Final considerations: this study can broaden the visibility of this visual art and insert it in the obstetrics, as well as its adoption by nurses, midwives and other health professionals in humanistic and holistic care for maternal health.

Descriptors: Art; Paint; Obstetrics; Nursing Theory; Humanization of Assistance.

\section{RESUMO}

Objetivo: apresentar o termo, o conceito e a técnica da arte de pintar o ventre materno. Método: estudo teórico, exploratório e qualitativo. Resultados: a partir dos resultados, foram elaborados o termo, fundamentado nas perspectivas linguística, filosófica e especializada, o conceito e a técnica da Arte da Pintura do Ventre Materno, norteados pelo humanismo e o holismo. Considerações finais: este estudo pode ampliar a visibilidade desta arte visual, inserindo-a no campo especializado da obstetrícia, bem como a sua adoção por enfermeiras, obstetrizes e outros profissionais de saúde no cuidado humanista e holístico à saúde materna.

Descritores: Arte; Pintura; Obstetrícia; Teoria de Enfermagem; Humanização da Assistência.

\section{RESUMEN}

Objetivo: presentar el término, el concepto y la técnica del arte de pintar el vientre materno. Método: estudio teórico, exploratorio y cualitativo. Resultados: a partir de los resultados, se elaboró el término, fundamentado en las perspectivas lingüística, filosófica y especializada, el concepto y la técnica del Arte de la Pintura del Vientre Materno, orientados por el humanismo y el holismo. Consideraciones finales: este estudio puede ampliar la visibilidad de esta arte visual, insertándola en el campo especializado de la obstetricia, así como su adopción por enfermeras, obstetras y otros profesionales de salud en el cuidado humanista y holístico a la salud materna.

Descriptores: Arte; Pintura; Obstetricia; Teoría de Enfermería; Humanización de la Atención. 


\section{INTRODUÇÃO}

Since prehistory, art has represented a basal activity of the human being, which, in producing objects and provoking certain psychic states in the recipient, does not end at all in these operations. It is in itself a specific way for people to relate to the universe and to themselves ${ }^{(1)}$ and to put them in a state of balance with the world around them ${ }^{(2)}$.

Art unites the individual to a whole and reflects the unlimited capacity for association to share experiences and ideas ${ }^{(2)}$. This makes it fundamental to human existence. Their use in the health field is not recent, nor is it in nursing.

This profession possesses art in its essence. This can be seen in the historical record of its precursor, Florence Nightingale, in the nineteenth century, in which she wrote that beautiful objects have effects on the disease, especially those bright and colorful. Effects do not occur only in the mind, but also in the body. From what little is known about how people are affected by form, color, light and brightness, it is known that they generate a real physical result, representing means for recovery ${ }^{(3)}$.

Florence's notes ${ }^{(3)}$ reveal that her perspective on the individual was comprehensive and, therefore, proposed the application of artistic elements in care, pointing to the possible implications of these in body and mind. Historically, nursing is interspersed by the humanistic paradigm, which facilitates the entry of integrative practices in this area. It is also holistic and some of its theories elucidate this aspect.

Hildegard Peplau, creator of Interpersonal Theory, conceptualizes nursing as a therapeutic, meaningful, interpersonal process that works cooperatively with other human processes that make health possible for individuals and communities. It is an educational tool, a force of maturity, that aims to move the personality in the direction of creativity, productivity, construction and community life ${ }^{(4)}$.

Myra Estrin Levine, in her holistic nursing model, addresses people as a dynamic whole. Martha Rogers, developer of the principles of hemodynamics, also focuses on all individuals. For her, the human being is a field of energy, irreducible, indivisible, pandimensional and identified by default, that benefits from Nursing that contributes in harmony with its process of chang $\mathrm{e}^{(5)}$. Wanda Horta ${ }^{(6)}$, in her Theory of Basic Human Needs, relies on the law of holism which defines that basic human needs are interrelated and integrate the human being, which is a whole.

Virginia Henderson's Theory of Basic Principles of Nursing contemplates the biological, psychological, sociological, and spiritual components, conceptualizing health as the ability of the self to function independently. She highlights the role of the nurse in promoting health and advocates that this professional should be at the forefront of preventive and creative care for citizens ${ }^{(5)}$.

The therapeutic properties of art have been known for centuries $^{(7)}$. Art has a positive impact on people's health, and can benefit mental, emotional and physical recovery, relieve anxiety, and decrease pain perception. It can be a tool for healing and stress relief, and can be applied in the community for the prevention, well-being promotion and communication of health information, for the acquisition of knowledge $\mathrm{e}^{(8)}$.

Increasingly, the arts have been treated as important components of comprehensive health ${ }^{(8)}$. They serve service users and caregivers as powerful support in times of emotional vulnerability and bring beauty to the world of health care, which has stress. They also touch spirits who seek encouragement and comfort, help to celebrate and build a community among clients, families, and health professionals ${ }^{(9)}$.

Art is born of a profound experience of reality, is elaborated and takes form through objectivity ${ }^{(2)}$. Its doing modifies the material offered by nature and culture, involving three dimensions: technique, mimesis and expression. That is, it provides the transformation, reproduction and representation of the signs and projects the inner life to the outside ${ }^{(1)}$. An artist collects, controls and transforms experience into memory, memory into expression and matter into form ${ }^{(2)}$.

It is based on the aforementioned perspectives that the Art of Maternal Womb Painting is developed, an artistic activity in which the technique of painting in the abdomen of pregnant women is applied to objectively represent the baby imagined by the mother (and her family) and other elements inherent to the intrauterine territory. This can be used in the obstetric care performed by the nurse, the midwife or other health professionals.

The first author of this study applied it in her professional practice and observed, empirically, that this visual art can influence the subjective experience of the attachment of the pregnant woman to her baby. Therefore, in his doctoral thesis entitled "Vivência da Arte da Pintura do Ventre Materno por Profissionais e Gestantes: Histórias, Emoções e Significados"studied this phenomenon ${ }^{(10)}$. From the results of this work, it established a theoretical body that culminated in the present article.

So far, no scientific studies have been done on this subject. It innovates by assigning scientificity to this visual art and by presenting, for the first time, its use in obstetrics.

\section{OBJECTIVE}

To present the term, concept and technique of art of maternal womb painting.

\section{METHOD}

\section{Ethical aspects}

This research was approved by the Research Ethics Committees of the Universidade Estadual de Campinas (Unicamp) (CAAE - Certificado de Apresentação para Apreciação Ética-Certificate of Presentation for Ethical Consideration: 48174715.1.0000.5404) and the Municipal Health Office of Curitiba (CAAE: 48174715.1.3001.0101). It respected the ethical precepts of Resolution 466/2012 of the Brazilian Health Board (Conselho Nacional de Saúde) ${ }^{(11)}$.

Figures showing the study participants and the scientist who collected the data come from the photographic records of the thesis, which were made after authorization, consent and signature of an Image Use Authorization Term.

\section{Study outlining}

This is a theoretical, exploratory, qualitative study, developed from the results of a doctoral thesis ${ }^{(10)}$ developed between 2014 and 2017, within the scope of the Graduate Program in Nursing of the Faculty of Nursing (FEnf - Faculdade de Enfermagem) of Unicamp. 
In Figure 1, the construction process of this article was demonstrated, showing the objectives, method and manuscripts resulting from the thesis ${ }^{(10)}$, which contributed to its elaboration.

The aforementioned thesis resulted in five articles. The first called "A arte de pintar o ventre materno: história oral de enfermeiras e obstetrizes"(19) aimed to describe when, how and why the nurse and midwife apply the painting in the womb of pregnant women. In it, the data from the thematic oral history of the seven health professionals interviewed were processed, based on Laurence Bardin's Thematic Content Analysis ${ }^{(15)}$. The collected speeches allowed to elaborate a historical tree of the painting in the womb and three categories of analysis emerged that reveal when, how and why the nurse and the midwife apply this art in care ${ }^{(19)}$.

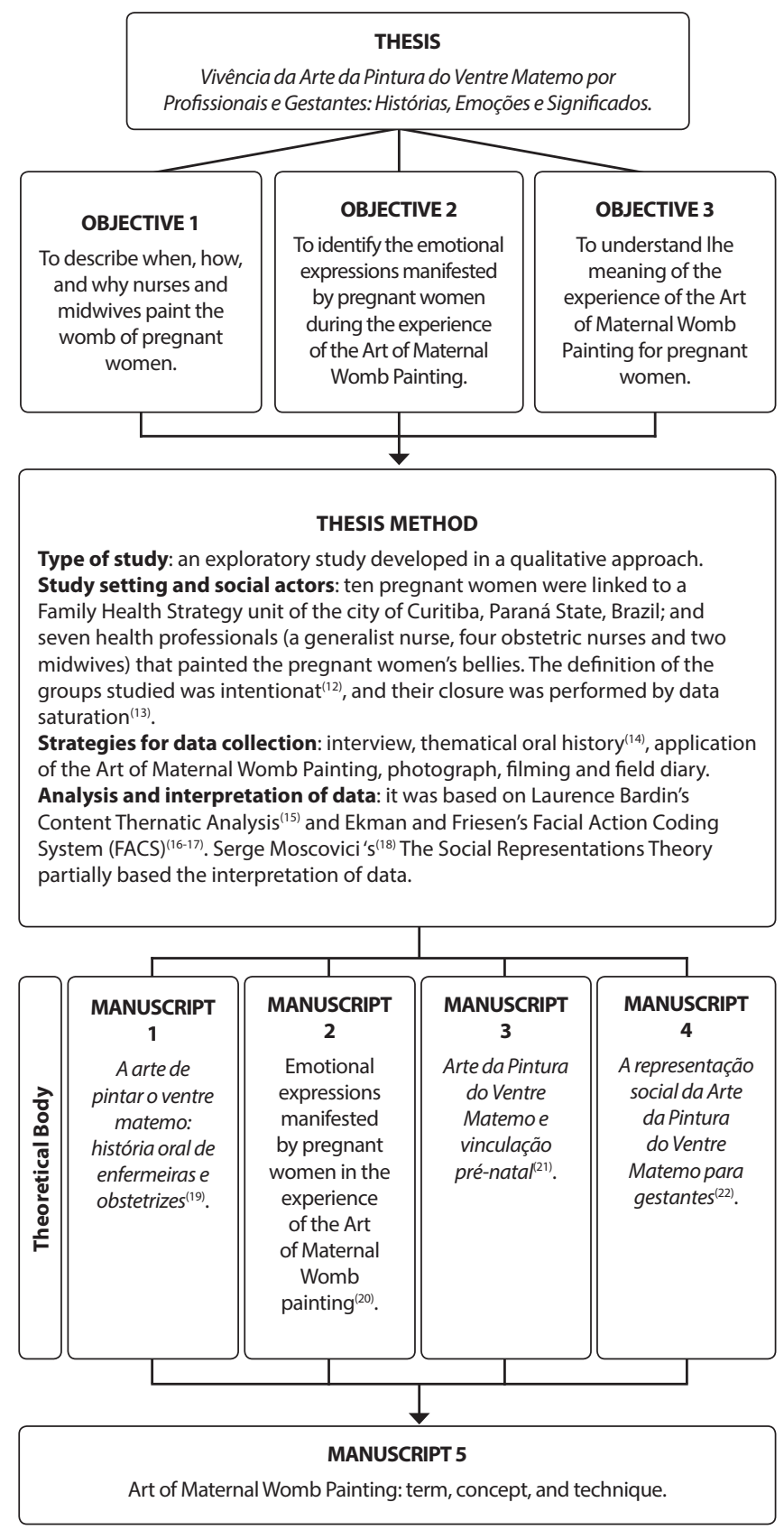

Figure 1 - Construction of this article based on the results of the thesis of the first author ${ }^{(10)}$, Campinas, São Paulo, Brazil, 2017
In the second article, "Emotional expressions manifested by pregnant women in the experience of the Art of Maternal Womb Painting"(20), which sought to identify the emotional expressions expressed by pregnant women in the experience of Art of Maternal Womb Painting, we analyzed the findings related to the emotions coded through the FACS and the records of the field diary. Thus, emotional manifestations of volunteers was identified as well as their characteristics, the order of appearance of emotions, and relationship with the history of each participant ${ }^{(20)}$. The third article, "Arte da Pintura do Ventre Materno e vinculação pré-natal"(21), which aimed to understand the meaning of the experience of the Art of Maternal Womb Painting for pregnant women, included the analysis of data originating from the interviews applied to pregnant women, at the time of the visual art and within three days after the interview. The interpretation culminated in two broad categories, which indicated that the meaning attributed by the participants to the Art of Maternal Womb Painting, in the technique developed by the first author, promoted the experience of the subjective core of attachment or love with the baby and positive maternal behaviors ${ }^{(21)}$.

The manuscripts called "A representação social da Arte da Pintura do Ventre Materno para gestantes "(22), the fourth of the work, involved the Thematic Analysis Content of the interviews with the pregnant women, based on Moscovici's Social Representations Theory' ${ }^{(18)}$. The emerging social representation at work was'l imagine, I see, I connect and approach my baby', strengthening the idea that the Art of Maternal Womb Painting promoted in women experiences of the subjective core of attachment or love with the fetus ${ }^{(22)}$.

The authors assembled the four articles and performed floating reading; identification of the main findings; classification in the categories "term, concept and technique"; and analysis and interpretation, based on literatures of Psychology, Nursing, Etymology, Arts, and Neuroscience. As a result of this, this work was elaborated, the fifth of the production, that theorizes about the Art of Maternal Womb Painting, its concept and technique.

\section{RESULTS}

\section{Definition of the term of "Art of Maternal Womb Painting"}

To define the term related to the art of painting the womb of pregnant women, an expanded view was taken, understanding that it is not only a technique of painting, but represents an artistic phenomenon with therapeutic purposes and that attributes objectivity to the psychic, maternal content, family, and even the nurse or midwife who applies it.

By means of traces and colors, this visual art consolidates the fantasies of the mother in relation to the characteristics of the being that is to come, previously belonging to the imaginary and now materialized in her skin. The imagined baby becomes visible, touchable, accessed and known by the woman/family/professional.

To paint the maternal womb is the act of bringing to the outside that which is inherent to the interior, revealing to the expectant eyes the imaginary baby and other elements of pregnancy. It is a doing that transforms, promotes knowledge, emotions ${ }^{(10)}$ and expresses intrauterine life through esthetic. Faced with this, it is imperative to call this technique "Art". It is, in essence, an artistic 
activity. By applying it, what nature and culture offer are transformed, combining images, sensations, and representations.

Its method involves painting directly on the pregnant woman's abdomen, so the words "painting", "belly" and "maternal" were also chosen to name it. The choice of the term "womb", which also means uterus, was due to the reason for this art to externalize and reveal, in a symbolic but objective way, what is in the intrauterine territory. With it, the fetus becomes a "child", a social being, part of the symbolic world of the mother/family, showing that it is not reducible to its genetic/biological organization, it exists, is a person and object of communication.

In the article called "A arte de pintar o ventre materno: história oral de enfermeiras e obstetrizes"(10,19) (see Figure 1 and Chart 1), it was verified that the painting done in the womb of pregnant women has a variability of definitions: natural ultrasound, belly painting, and gestational ultrasound. The first one was created by the midwife Naolí Vinaver, around 1996. The others originated in the practice of the professionals studied, in the search to offer women an accessible communication and a better understanding of this technique.

It is emphasized that Naolí created the name "natural ultrasound" in a historical moment marked by interventionism and the excessive use of technology in the pregnancy cycle. Her intention was to show that through art the midwife could reveal the approximate size and precise position of the fetus as well as conventional ultrasound. She sought to compete with the indiscriminate application of obstetrical ultrasound, questioning empirically the risks offered to the mother-baby binomial. This professional was a pioneer in the implementation of painting in pregnant women, in Brazil and internationally.

In the current perspective of obstetric care, which seeks to abolish the predominance of the technocratic approach, adopting the humanist and/or holistic approach, to denominate the painting of the maternal womb as "ultrasound" attributes a medicalized dimension to this art, which is opposite to its nature and purpose. Therefore, it is recommended to use the term "Art of maternal womb painting" which, in the authors' conception, reflects the essence of this artistic and therapeutic activity.

\section{Concept of Art of Maternal Womb Painting}

The concept of Art of Maternal Womb Painting, proposed in this research, was based on the main results of the thesis, as shown in Chart 1.

In view of the above in Chart 1, the Art of Maternal Womb Painting is conceptualized as an artistic and therapeutic activity that involves a painting technique applied in the abdomen of the pregnant woman, in which the imaginary baby and other elements related to the pregnancy are represented objectively, such as the umbilical cord, the placenta, the uterus and the bag of waters. It is a practice that can be applied by nurses, midwives and other health professionals who work in obstetric care.

This visual art encourages, in the pregnant women, experiences of the subjective nucleus of the attachment or of love with the baby, having potential to promote prenatal attachment. In addition, it elicits positive behaviors and positive feelings for adjustment during pregnancy cycle and maintenance of maternal well-being.
Chart 1 - Results of the thesis ${ }^{(10,19-22)}$ which support the concept of Art of Maternal Womb Painting, presented in this research, Campinas,São Paulo, Brazil, 2017

\begin{tabular}{|c|c|}
\hline $\begin{array}{l}\text { Manuscripts } \\
\text { of the thesis }\end{array}$ & Main results that based the concept \\
\hline $\begin{array}{l}\text { 1. A arte de pintar } \\
\text { o ventre materno: } \\
\text { história oral de } \\
\text { enfermeirase } \\
\text { obstetrizes }^{(19)}\end{array}$ & $\begin{array}{l}1.1 \text { Various forms of application of painting in } \\
\text { womb of pregnant women were identified, } \\
\text { which relate to the professionals' abilities } \\
\text { to draw and paint, to the time and material } \\
\text { available, to the participation or not of } \\
\text { third parties in the painting process, to the } \\
\text { philosophy of care and to the intentionality of } \\
\text { each of them. } \\
1.2 \text { Womb painting of pregnant women has } \\
\text { been adopted by the nurse and the midwife } \\
\text { in prenatal care and within the maternity } \\
\text { as a strategy of health education and in the } \\
\text { promotion of maternal and family well-being. }\end{array}$ \\
\hline $\begin{array}{l}\text { 2. Emotional } \\
\text { expressions } \\
\text { manifested by } \\
\text { pregnant women } \\
\text { in the experience } \\
\text { of the Art of } \\
\text { Maternal Womb } \\
\text { Painting }\end{array}$ & $\begin{array}{l}\text { 2.1 During the experience of the Art of Maternal } \\
\text { Womb Painting, the pregnant women manifested } \\
\text { six universal emotions, such as fear, joy, surprise, } \\
\text { sadness, anger, and disgust. } \\
2.2 \text { The emotions manifested with unanimity } \\
\text { were fear, joy and surprise. } \\
2.3 \text { Disgust, anger and sadness appeared less } \\
\text { frequently and were short-lived. } \\
\text { 2.4. Pregnant women who expressed emotions } \\
\text { that may be negative had particularities in their } \\
\text { life histories, such as early pregnancy; unwanted } \\
\text { and/or unplanned pregnancy; loss of a child; } \\
\text { marital problems; high-risk pregnancies; and } \\
\text { signs of low self-esteem. } \\
\text { 2.5The experience of the Art of Maternal Womb } \\
\text { Painting enabled the pregnant women to express } \\
\text { their most primitive or unpleasant emotions, } \\
\text { being able to collaborate for a moment of } \\
\text { catharsis in pregnancy. }\end{array}$ \\
\hline $\begin{array}{l}\text { 3. Arte da Pintura } \\
\text { do Ventre Materno } \\
\text { e vinculação pré- } \\
\text { natal(21) }\end{array}$ & $\begin{array}{l}\text { 3.1 The Art of Maternal Womb Painting promoted } \\
\text { in the pregnant women four experiences of the } \\
\text { subjective nucleus of attachment or love with } \\
\text { the baby, being: the disposition to know, to be/ } \\
\text { interact with, to avoid separation or loss and to } \\
\text { protect the baby. } \\
\text { 3.2 The main behaviors and feelings generated by } \\
\text { the experience of Art of Maternal Womb Painting } \\
\text { were: imagining the baby, seeking to know about } \\
\text { him and pregnancy, awareness of fetal positions, } \\
\text { feeling of closeness of the fetus, protecting the } \\
\text { baby represented in the painting, relaxation and } \\
\text { personal appreciation of pregnant women. }\end{array}$ \\
\hline $\begin{array}{l}\text { 4. A representação } \\
\text { social da Arte da } \\
\text { Pintura do Ventre } \\
\text { Materno para } \\
\text { gestantes }^{(22)}\end{array}$ & $\begin{array}{l}\text { 4.1 The social representation on the Art of Maternal } \\
\text { Womb Painting, emerging in the speeches of the } \\
\text { pregnant women, was"I imagine, I see, I connect and } \\
\text { lapproach my baby". }\end{array}$ \\
\hline
\end{tabular}

Mothers who experience the Art of Maternal Womb Painting express, for the most part, emotions that can be positive, such as joy and surprise. Some have emotional manifestations that can be considered negative, being intrinsically related to their emotional triggers. It allows women to externalize in the pregnancy period their most primitive or unpleasant emotions, favoring catharsis.

This art is represented by pregnant women as something positive that stimulates their imagination in relation to the fetus, because it allows to visualize it and, consequently, causes feelings of approximation and connection with him. 
It is recommended to those who are interested in learning more about the experience of this phenomenon and its repercussions, as well as the studies cited ${ }^{(19-22)}$ in Chart 1, the reading of the thesis ${ }^{(10)}$ that originated this article.

\section{Technique description}

In article $1^{(19)}$ (see Figure 1), it was found that nurses and midwives have applied paint in the pregnant women's womb in various ways. They palpate the woman's abdomen; some use baby molds to draw, interfering in the maternal/family imaginary; others draw freehand; use paint for facial/body/artistic painting, make-up or gouache paint; paint with your fingers, brushes and/ or sponges. They develop art in different moments of pregnancy, and most prioritize the third trimester ${ }^{(19)}$.

In its genesis, the Art of Maternal Womb Painting consists in making external what is in the uterine territory and in the mother's psyche. The idealized and fantasized baby is embodied, revealing itself to the expectant eyes. In it, the first step is to stimulate the exercise of elaborating and imagining the fetus, of describing it and thus inserting it into the symbolic world of the pregnant woman/family. Personification and representation that the mother/family makes of the being that is to come is fomented.

Showing a ready image of a baby to the pregnant woman/ family, so that she can choose what is drawn and painted, as it is exercised by some professionals, interferes in this process. In this situation, the result of the painting ceases to be the reflection of the imaginary content of the woman/family and makes an inverse movement, from the external to the internal. It infuses to the mother/family something predefined, strange to her and impregnated of the influences of the outside world.

Regarding materials used for the art performance, the artistic freedom of each professional is defended, provided that the products adopted are non-toxic and suitable for application to human skin. The use of gouache paint is not indicated.

It is recommended to use the following components: paint for facial/artistic/body painting (liquid, creamy and/or pancake blush); glitter; soft bristle brushes for painting or makeup of various sizes (16, 8 and 6, for example); eyeliner pencil in black and/or brown colors; sponges for makeup; make-up remover (moist wipes can also be used); a glass with water, to clean the brushes; spray with water, for the pancake; cotton discs, for the use of a make-up remover; a fetal Doppler sonar, or a Pinard stethoscope to auscultate the heartbeat if direct auscultation is not performed. If sonar is used, a conductive gel will also be required.

Data collection during thesis production ${ }^{(10)}$ started with the pregnant women, and later on, it was carried out with nurses and midwives. The first author took this measure to avoid that her technique of painting of the womb suffered influence of those practiced by professionals in the study.

Maternal womb painting, developed in the production of the research, was carefully recorded by photographs and field notes. The records made were based on the technique described below.

The Art of Maternal Womb Painting must be developed in five steps:
- Step 1 - Encourage the pregnant woman to describe the imaginary baby: first, the health professional should ask the pregnant woman if she imagines what her baby looks like. If the answer is positive, it encourages the mother to describe the imagined baby. If negative, it raises your imagination. Family and other people present may also participate in the making of art, but it is important that women have space to express their psychic content first, without external interference.

- Step 2-Maternal positioning and obstetric palpation (Leopold Zweifel maneuver): the pregnant woman should be positioned comfortably, according to her choice. If lying down, placing rests on the head, shoulders and back may be a good option. Cushions and/or pillows may be used, with a $30^{\circ}$ elevation recommended. If the development of the art takes place in a health service, the stretcher or bed may have its headboard elevated. If it is painted on an armchair, it is recommended to keep a slight incline of the trunk back. The woman needs to be free to move and change position when she wishes and the professional must offer this information before starting the technique. With warm hands, the health professional can start the Leopold Zweifel maneuver, performing his first three times: situation, position and fetal presentation (Figure 2). At that moment, she (he) can encourage the pregnant/family to touch the parts of the baby. In addition, it can develop perinatal education, explaining about the growth and development of the fetus, the functions of the placenta and umbilical cord, amniotic fluid, uteroplacental exchanges, etc. It is recommended to apply the art from 24 weeks of pregnancy, when it is possible to perform the Leopold Zweifel maneuver and, consequently, represent the baby objectively.

- Step 3 - Auscultation of the fetal heart rate (Figure 2): after confirmation of the situation, position and fetal presentation, the fetal heart rate (FHRs) can be done with a fetal Doppler sonar, a Pinard stethoscope, or of direct auscultation. At this stage, some pregnant women/families tend to get emotional because, through the FHRs, the baby reveals its existence and becomes even more present. The professional can draw a heart in the place where she identified the maximum auscultation focus, teach and encourage the pregnant woman/family to listen directly to the FHRs, when they wish.

- Step 4-Draw of the imaginary baby described by the mother and elements related to pregnancy (Figure 3): the professional draws free hand the contours of the described baby's body according to the situation, position, presentation and its approximate size. The professional traces the umbilical cord and placenta and then contours the images simulating the uterus. Other drawings required by the mother/family may be included, such as a frame around the uterus including flower petals, asymmetrical lines, curves, baby's name, etc.

- Step 5 - Painting of the drawings (Figure 4): with the paint for body painting, fill the drawings with brushes of various sizes. If pancake is used, sponges will also be used for paint. It begins with the body of the baby, the uterus and the amniotic fluid, then the umbilical cord and placenta are painted, and finally the frame, when requested. The colors applied in the baby should approximate what was described by the pregnant woman (skin color, eyes 
and hair, for example). As for the umbilical cord and the placenta, it is recommended to apply the shades of red and blue in order to simulate the actual uteroplacental circulation. The amniotic fluid may be represented by the white color, and the application of glitter in the space representing the amniotic pouch helps to give a liquid effect. The parent, relatives and/or friends present at the time of painting can be invited to assist, if it is the mother's wish, as an opportunity to promote interaction and establish/strengthen links.

During steps 4 and 5, it is important to interact with the mother/family, exercising qualified listening, and seeking to collect meaningful data to plan the care to be performed. Orientations can also be offered, according to the needs of the woman/family, representing an opportunity for health education.

After completing the Art of Maternal Womb Painting (Figure 5), the professional can reveal it to the pregnant woman through a mirror and observe it. This is an excellent opportunity to evaluate the aspects related to maternal/family adaptation to pregnancy and to the subjective experience of attachment or love between mother and fetus.

The length of stay of the painting is variable. The pregnant woman can remove it in the bath with soap and water. The drawing made with the eyeliner pencil comes out easily with the aid of a make-up remover. It was found in the research that most of the pregnant women wanted to spend more time with the art in their body, some remained more than a day with it ${ }^{(10)}$.
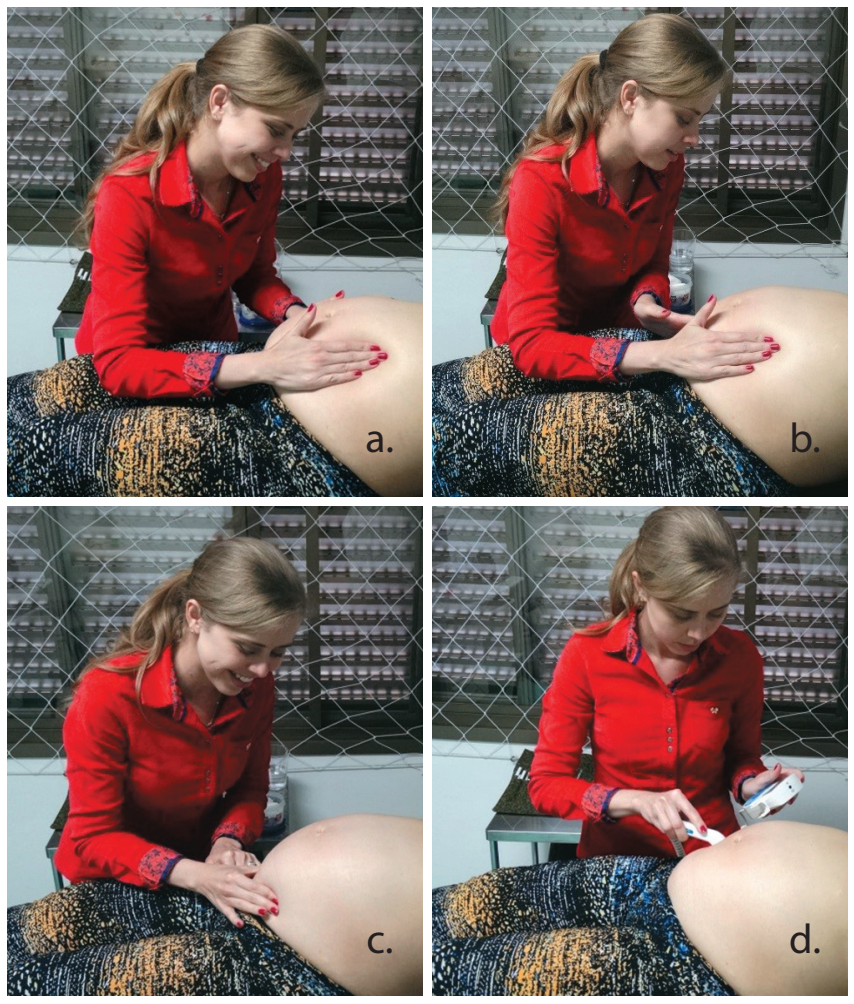

Figure 2 - Sequence of photos showing steps 2 (a. situation, b. position, c. presentation) and 3 (d. Auscultation of the FHRs) of the Art of Maternal Womb Painting, Campinas, São Paulo, Brazil, 2017

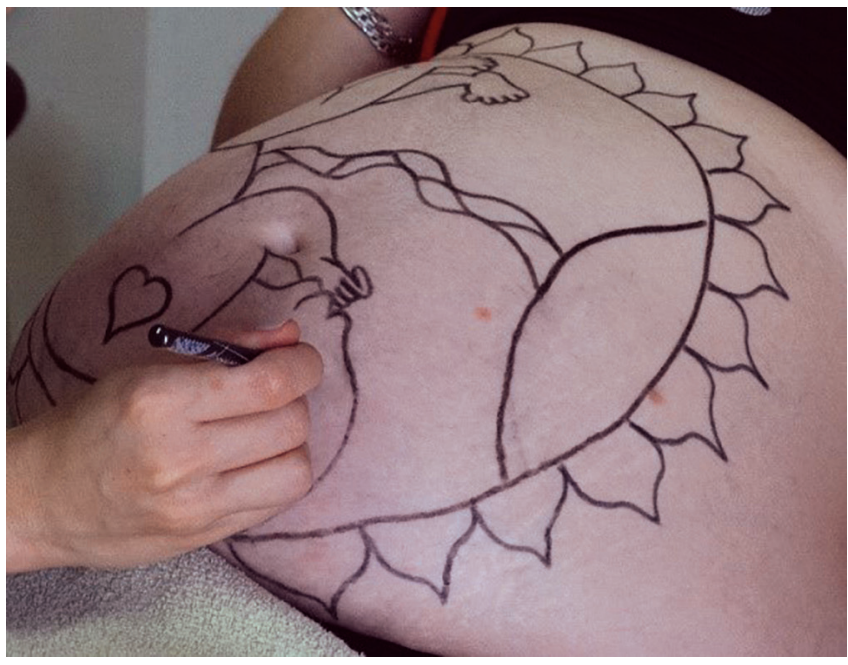

Figure 3 - Step 4 of the application of Art of Maternal Womb Painting

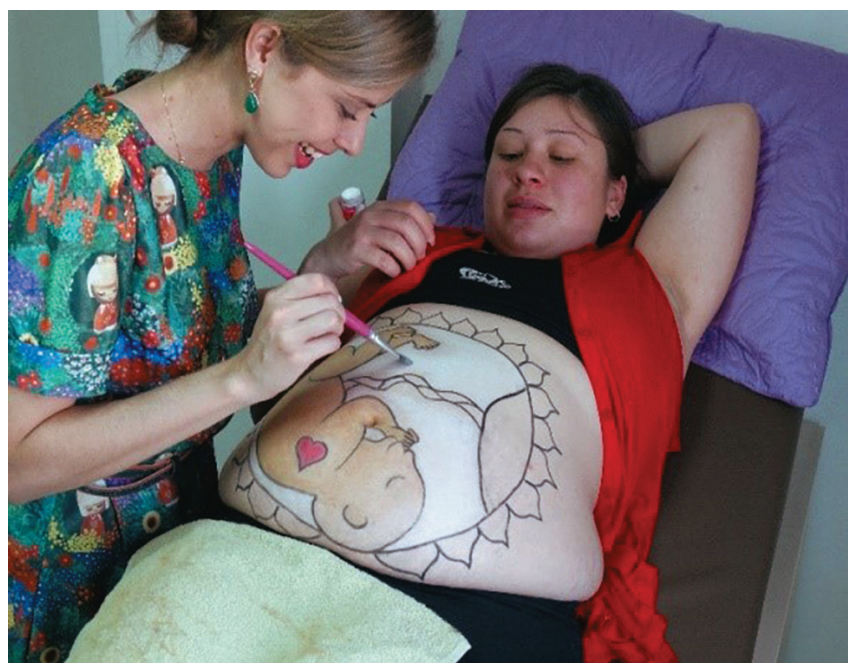

Figure 4 - Step 5 of the application of Art of Maternal Womb Painting

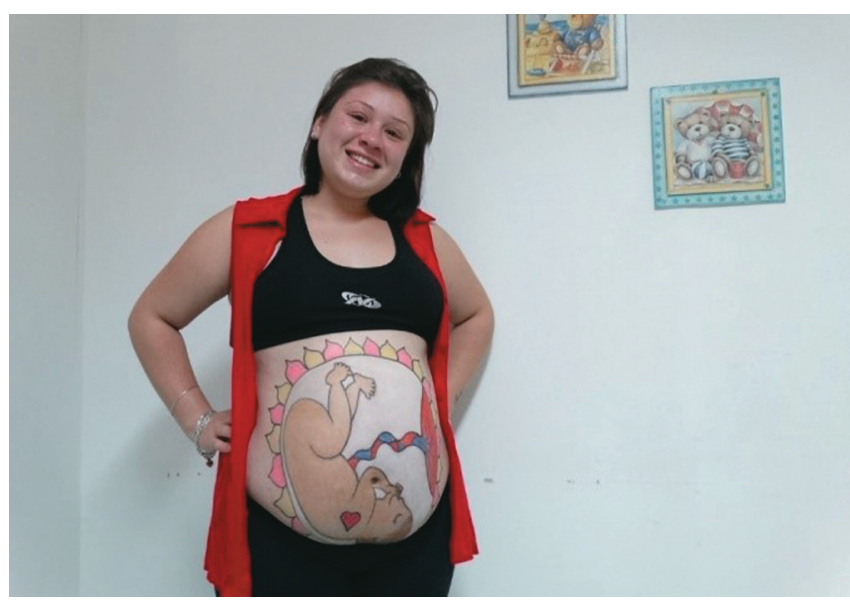

Figure 5 - Art of Maternal Womb Painting finalized. Photo of thesis collection $^{(10)}$, with permission to use the image, Campinas, São Paulo, Brazil, 2017

\section{DISCUSSION}

The conception of the term "Art of Maternal Womb Painting" was based on three perspectives: linguistic, philosophical and specialized. These areas converge, considering that the term 
has an essential purpose and therefore has a functional value, although they differ in their conception (linguistics - unity of meaning, philosophy - unit of cognition, specialties - unit of denomination) and delimitation of its function ${ }^{(23)}$.

For linguistics, the term is considered a linguistic sign that integrates the lexical component of the grammar of the speaker. It is a unit of the grammatical lexicon that is part of the competence of the speaker, which can be general, when common to all speakers, or specialized, when restricted to groups. It is considered a way of knowing and has the function of giving meaning ${ }^{(23)}$.

In philosophy, the term is a cognitive unit that represents specialized knowledge. Their role is to represent, giving an idea of the organization of the specialized world or, at least, how individuals perceive this world. It is a way to know and represent an organized reality ${ }^{(23)}$. In the field of specialties, it is a unit of expression and communication that facilitates the transfer of specialized thinking, being a form of transference and communication, with the function of denominating ${ }^{(23)}$.

Each of the aforementioned perspectives prioritizes distinct aspects of the term object. Linguistics focuses on the name-meaning relationship, prioritizing meaning; philosophy, thing-meaning, focusing on cognition and representation; and the specialties, thing-name, focusing on the denomination for the transference ${ }^{(23)}$.

The "Art of Maternal Womb Painting" term originated from linguistic and philosophical elements, within the specialty of obstetrics, being: units of meaning present in the speeches of pregnant women and health professionals who have come into contact with this phenomenon; the social representation of the experience of this visual art for the pregnant women; and the lived of the scientist who applied the artistic technique in the data collection in the obstetric field. In the definition of the above term, the common points of linguistics, philosophy and specialties were considered in order to theorize this new knowledge.

The purpose of this term is: to signify to the practice of painting the womb of pregnant women; promote knowledge about it, elucidating its representation in the social world; and name it within the health area. To elaborate it, we considered the meaning and origin of the words. The first word chosen was "Art" (noun), originating from the Latin ars, which means technical knowledge, skill acquired by the practice ${ }^{(24)}$. It is at the root of the verb "articulate", meaning the action of making joints between the parts of a whole(1).

Art involves a set of acts by which the signs of nature and culture are transformed. It is also a mode of representation, a way to know. Any human activity, if regularly conducted to an end, may be called artistic (1). The Art of Maternal Womb Painting is an artistic activity that uses aesthetics in obstetric care to promote subjective experiences of attachment or love between motherfetus and promoting maternal/family health.

Painting (noun), Womb (noun) and Maternal (adjective) originate from the following Latin words and their respective meanings: pictura - art of painting, work of painting; venter - abdomen, belly. It gives meaning also to uterus, which denotes uterus, fetus, child in the womb; and maternus - maternal ${ }^{(24-25)}$.

The term presented here is based on an extended perspective in relation to this art, because we understand it beyond the technique of painting, the ability to draw a picture. It represents the content present in the maternal/family psyche, since it involves the expression of the imaginary baby, which is the mental image of the fetus, elaborated by the woman (or parents) during pregnancy ${ }^{(26)}$. This character is marked by fantasies and idealizations $^{(27)}$ that permeate the first relations between mother-child, and it is in relation to her that the emotional bond develops ${ }^{(28)}$.

To a certain extent, painting also represents what is in the nurse/midwife's imagination (or other health professional) who, with his artistic freedom, goes beyond the limits of what he feels with his hands, through palpation, creating frames with diverse images and applying colors that are not characteristic of the intrauterine environment, but which express their way of producing the art and reveal by aesthetic their personality and that of who is painted.

In her theory, Wanda Horta ${ }^{(6)}$ considers that the creative and imaginative use of knowledge for the improvement of the human being finds expression in the art of nursing. Her practice is imaginative and creative, grounded in abstract knowledge, intellectual judgment, and compassion.

In the Art of Maternal Womb Painting, the subjective and the objective intertwine to materialize the gestational experience and to embody the being that is to come. The abdomen becomes the canvas that illustrates maternal and family fantasies and also objectively expresses what is inside the womb. It is, in its essence, art, because it transforms what nature and culture offer us, expressing representations, emotions and feelings.

In a scientific research ${ }^{(19)}$ on nurses and midwives who apply paint in the womb of pregnant women, a diversity of definitions was verified related to the reason for its performance and to the need to offer more understandable terms to the women/families who they experience it. Among them, "natural ultrasound" stands out and is conceived by the precursor of this practice, Naolí Vinaver. We are opposed to it, because we believe that the word "ultrasound" attributes a medicalized and technologized perspective to the art of painting the mother's womb.

It should be noted that the term "natural ultrasound"emerged in a historical period characterized by medicalization, being chosen by Naolí in order to compete with the abusive use of obstetric ultrasound, showing that the midwife can also reveal to the woman the precise position and approximate size of the baby ${ }^{(10,19)}$. This term was influenced by the social-historical moment in which it was defined.

The creation of the "Art of Maternal Womb Painting" term was also based on humanistic and holistic paradigms ${ }^{(29)}$. The first one recognizes the interconnection between mind and body, focusing care strategies that influence these two elements ${ }^{(29)}$, understanding that addressing psychic and emotional aspects has repercussions on physiology and vice versa. The woman is understood as a subject and not as an object. Therefore, the search for the establishment of a human relationship in which a connection with the person emerges and the knowledge about $\mathrm{it}^{(29)}$. Interaction and communication are therapeutic tools. Knowing how to listen is as important as knowing how to say. Care is driven by empathy and respect for individuality ${ }^{(29)}$.

The second paradigm is based on the unity of body, mind and spirit. In this, the dedication to the psychological aspects that influence in pregnancy is considered useful and essential part of care. It 
also covers the metaphysical world, treating the body as an energy system connected to other energy systems. Being is approached in its entirety, without fragmentation, and the context of life has great significance. Holistic care lends credence to the inner or intuitive (non-rational perception) knowledge of the person, considers information that arises from the deep interiority of the subject ${ }^{(29)}$.

Nursing is essentially humanistic and holistic, since its theories ${ }^{(3-6)}$ value the biological, psychological, social, cultural, historical, and spiritual dimensions of care for individuals. In this profession, the human being is seen as a whole ${ }^{(5-6)}$, it is an energy field that cannot be fragmented, reduced or approached in a one-dimensional way. Human has basic multidimensional needs that are interrelated ${ }^{(6)}$ and his/her health is influenced by his/her individuality, the environment and the communities that surround him.

The assumptions cited did not only guide the definition of the term "Art of Maternal Womb Painting" but also its concept and technique. The conceptualization presented in this manuscript covers the making and the purpose of this visual art, also being based on the findings of the thesis that ground this work ${ }^{(10)}$, which recorded the technique, unveiled its social representation and identified the emotional manifestations triggered by it.

In view of the above, it is argued that it is imperative to approach the maternal psychic content in this art and, therefore, to involve the narrative about the imaginary baby that can have repercussions on the experience of the subjective nucleus of attachment or love between mother-fetus ${ }^{(10,21,28)}$, emotions ${ }^{(20)}$ and maternal behaviors ${ }^{(10,21)}$.

The social representation of the Art of Maternal Womb Painting for pregnant women, emerging in research, elucidates that it means a positive experience that makes it possible to imagine, visualize, approach and connect to the baby ${ }^{(10,22)}$. Obstetric care health professionals can insert it into their care repertoire to promote the attachment experience, perinatal education, and maternal and family health. The nurses and midwives investigated in the thesis ${ }^{(10)}$ showed intuitively and empirically these possibilities.

The Art of Maternal Womb Painting has therapeutic focus. It is not only a matter of painting the pregnant woman with an artistic purpose. Their way of doing integrates physiological, psychic, cultural, social, historical components, values and beliefs; promotes expression, emotions, subjective experience of attachment or love between pregnant-fetus and pregnant-professional and pregnant-family-professional interaction/integration ${ }^{(10)}$. It is a valuable resource of care for those who wish to promote maternal health under the humanistic and holistic.

\section{Study limitations}

The authors of this research defend the humanistic and holistic paradigms, as well as the use of Art of Maternal Womb Painting as therapeutic practice in obstetrical care, which offered a risk of tendencies in the study. To mitigate this risk, the production of the data was done carefully, guaranteeing the scientific rigor. In addition, the results and inferences were analyzed and discussed with five other health professionals and scientists (four nurses and one doctor), external to the collection, that contributed to manage this limitation.

\section{Contributions to Nursing and Health}

This research assigns scientificity to the Art of Maternal Womb Painting, inserting it in the specialized field of nursing and obstetrics. It establishes a new body of knowledge that can broaden and subsidize the application of this visual art in maternal health care and the accomplishment of new research on the subject that can give robustness to nursing theory and practice.

\section{FINAL CONSIDERATIONS}

In the research, the scientific approach of Art of Maternal Womb Painting is inaugurated. The term and concept presented can support the treatment of this theme in new investigations and promote its insertion in the specialized field of nursing and obstetrics. The detailed description of this visual art can guide nurses, midwives and other health professionals in their application and enable their replication in different practice settings and further studies.

It is recognized that there are limitations on the knowledge about the effects that this technique can generate. Therefore, it is considered that it is necessary to carry out further research to give greater robustness to the theoretical body produced up to now, including also controlled studies and quantitative approach.

It is hoped that this new object of science and obstetric practice will be seen and treated from the point of view that conceived it, as an artistic, transformative activity with a humanizing and holistic potential that contrasts with the technocratic model of maternal health care, representing a therapeutic possibility for prenatal and in-hospital care. With this work, it is hoped to have expanded the visibility of this visual art, so that it is developed in new spaces, reflected, discussed and researched.

\section{REFERENCES}

1. Bosi A. Reflexões sobre a arte. 7a ed. São Paulo: Editora Ática; 2008.

2. Fischer E. A necessidade da arte. 9a ed. Rio de Janeiro: LTC; 1987.

3. Nightingale F. Notes on nursing: What it is and what it is not. New York: D. Appleton and Company; 1860.

4. Peplau HE. Interpersonal relations in nursing: a conceptual frame of reference for psychodynamic nursing. New York: Spring Publishing Company; 1991.

5. George JB. Teorias de enfermagem: os fundamentos à prática profissional. 4ª ed. Porto Alegre: Artes Médicas; 2000.

6. Horta WA. Processo de enfermagem. São Paulo: EPU; 1979. 
7. Staricoff RL. Arts Council England. Research report 36. Arts in health: a review of the medical literature [Internet]. London: Arts Council England; 2004 [cited 2017 Jan 30]. Available from: http://www.creativenz.govt.nz/assets/ckeditor/attachments/1030/staricoff_r_arts_in_ health.pdf?1410235845

8. Rollins J, Sonke J, Cohen R, Boles A, Li J. State of the Field Committee. State of the field report: Arts in healthcare [Internet]. Washington: Society for the Arts in Healthcare; 2009 [cited 2017 Jan 30]. Available from: https://www.americansforthearts.org/sites/default/files/ ArtsInHealthcare_0.pdf

9. National Endowment for the Arts and Society for the Arts in Healthcare. The arts in healthcare movement in the United States [Internet]. Washington: The Arts in Healthcare Symposium; 2003 [cited 2017 Jan 30]. Available from: https://www.arts.gov/sites/default/files/NEA_ SAHConceptPaper.pdf

10. Mata JAL. Vivência da Arte da Pintura do Ventre Materno por Profissionais e Gestantes: Histórias, Emoções e Significados [Tese] [Internet]. Campinas: Universidade Estadual de Campinas; 2017 [cited 2018 Jun 18]. Available from: http://repositorio.unicamp.br/jspui/handle/ REPOSIP/332878

11. Ministério da Saúde (BR). Conselho Nacional de Saúde. Comissão Nacional de Ética em Pesquisa. Resolução nº 466 de 12 de dezembro de 2012. Dispõe sobre as diretrizes e normas regulamentadoras de pesquisas envolvendo seres humanos [Internet]. Brasília: Ministério da Saúde; 2012 [cited 2017 Jan 30]. Available from: http://bvsms.saude.gov.br/bvs/saudelegis/cns/2013/res0466_12_12_2012.html

12. Polit DF, Beck CT. Fundamentos de Pesquisa em Enfermagem: avaliação de evidências para a prática da enfermagem. $7^{a}$ ed. Porto Alegre: Artmed; 2011.

13. Fontanella BJB, Ricas J, Turato ER. Amostragem por saturação em pesquisas qualitativas em saúde: contribuições teóricas. Cad Saúde Pública. 2008;24(1):17-27. doi: 10.1590/\$0102-311X2008000100003

14. Alberti V. Manual de história oral. 3a ed. Rio de Janeiro (RJ): Editora FGV; 2013.

15. Bardin L. Análise de conteúdo. Lisboa: Edições 70; 2009.

16. Ekman P, Friesen WV. Facial Action Conding System: A technique for the measurement of facial movement. Palo Alto: Consulting Psychologists Press; 1978.

17. Ekman P, Friesen WV, Hager JC. Facial Action Coding System. Arizona: A Human Face; 2002.

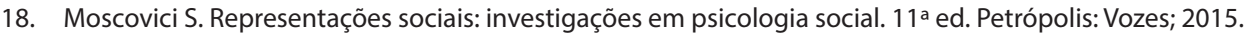

19. Mata JAL, Shimo AKK. A arte de pintar o ventre materno: história oral de enfermeiras e obstetrizes. Enferm Actual Costa Rica. 2018;35 doi: 10.15517/revenf.v0i35.31555

20. Mata JAL, Silva MG, Shimo AKK. Emotional expressions manifested by pregnant women in the experience of the art of maternal womb painting. Health Care Women Int 2018;39(11):1275-94. doi: 10.1080/07399332.2018.1488853

21. Mata JAL, Shimo AKK. Arte da pintura do ventre materno e vinculação pré-natal. Rev Cuid. 2018;9(2):2145-64. doi: 10.15649/cuidarte.v9i2.499

22. Mata JAL, Shimo AKK. A representação social da arte da pintura do ventre materno para gestantes. Rev Pesqui Qual [Internet]. 2017 [cited 2017 Mar 16];5(8):250-68. Available from: https://editora.sepq.org.br/index.php/rpq/article/view/113

23. Cabré MT. La terminología hoy: concepciones, tendências y aplicaciones [Internet]. Ci Inf. 1995 [cited 2018 Jun 18];24(3). Available from: http://revista.ibict.br/ciinf/article/view/567

24. Rezende AM, Bianchet SB. Dicionário de latim essencial. 2a ed. Belo Horizonte: Autêntica Editora; 2014.

25. Simões RS, Girão JHRC, Sasso GRS, Silva RF, Alonso LG, Marques SR. Etimologia de termos morfológicos. São Paulo: UNIFESP; 2014.

26. Stern DN. A constelação da maternidade: o panorama da psicoterapia pais/bebê. Porto Alegre: Artes Médicas; 1997.

27. Stern DN, Bruschweiller-Stern N. The birth of a mother. 1st ed. New York: Basic Books; 1999.

28. Condon JT. The assessment of antenatal emotional attachment: development of a questionnaire instrument. Br J Med Psychol. 1993;66:16783. doi: 10.1111/j.2044-8341.1993.tb01739.x

29. Davis-Floyd R. The technocratic, humanistic, and holistic paradigms of childbirth. Int J Gynecol Obstet. 2001;75:S5-23. doi: 10.1016/ S0020-7292(01)00510-0 